\title{
Correlation between Actual Compressive Strength of Concrete and Strength Estimated From Core
}

\author{
${ }^{[1]}$ Dr. Suresh. G. Patil, ${ }^{[2]}$ Shivakumar \\ ${ }^{1}$ Professor and Head of the Department, P.D.A College of Engineering, Kalaburagi-585102 \\ ${ }^{2}$ M.Tech student, P.D.A College of Engineering, Kalaburagi
}

\begin{abstract}
The estimation of mechanical properties and strength of concrete can be carried out by several methods; destructive and non destructive. In this study crushing strength of concrete cubes is the usual destructive test to determine the compressive strength of concrete. The rebound hammer test, ultrasonic pulse velocity and core test are the non destructive tests to determine compressive strength of concrete and to obtain correlation between them. In this work using $M-20$ grade of concrete twelve numbers of concrete cubes of size (150mmx150mmx150mm) were cast using the water cement ratio 0.55. The five numbers of slabs of size $500 \mathrm{~mm} \times 500 \mathrm{~mm}$ with $120 \mathrm{~mm}$ thickness were made by same water cement ratio. An experimental study was conducted to determine the correlation between actual compressive strength of concrete cubes and strength estimated from cores having different $H / D$ ratio $(1.5,1.75$ and 2.0$)$ and diameter of $50 \mathrm{~mm}$. totally thirty numbers of cores were extracted from the concrete slabs, fifteen numbers of cores were extracted from concrete portion (without reinforcement) and other fifteen numbers of cores were extracted with reinforcement. The results indicate that the cores with reinforcement of $H / D$ ratio $1.5,1.75$ and 2.0 indicate greater compressive strength as compared to cores free from reinforcement for the same H/D ratio and core compressive strength increases with increase in the H/D ratio. The very good correlation coefficient (0.979) is obtained.
\end{abstract}

\section{Introduction}

It is often necessary to test concrete structures after the concrete has hardened to determine whether the structure is suitable for its designed use. Ideally, such testing should be done without damaging the concrete. The test available for testing concrete range from completely non-destructive tests, where there is no damage to the concrete, through those where the concrete surface is slightly damaged to partially destructive tests, such as core tests and pull-out and pull-off tests, where the surface has to be repaired after the test. Coring is usually the method ultimately chosen to determine in-situ compressive strength of concrete. In concrete structures with a lot of reinforcement bars, it may be impossible to obtain a core specimen from which compressive strength may be taken since reinforcing steel may be so prevalent in the concrete. The size of core taken in diameter should be minimum three times of maximum size aggregate than used in the structure. In structures using larger aggregates, it may be practical to take cores larger in diameter, but costs increase rapidly and the large core usually cannot be taken deeper. Coring may prove expensive and holes have to be back filled, but the resulting data are usually accepted as the best evidence of the condition of concrete in place.

Sanita Rubene, obtained the relationship between compressive strength of concrete cubes and rebound number of the concrete cubes using rebound hammer test. They prepared 20 cubes in the field of size 100x100x100 mm. The concrete cubes are cured for 28 days. Then the concrete cubes are tested in laboratory and were also tested with a Schmidt rebound hammer using two different impact directions on each testing points such as horizontal impact and vertical impact. A series of 10 rebounds were carried out for each test. Significantly the test results obtained by the Schmidt rebound hammer showed that higher than the results obtained by testing of concrete cubes ${ }^{[1]}$. P. Turgut obtained the relationship between concrete strength and UPSV by using data obtained from many cores taken from different reinforced concrete structures having different ages and unknown ratios of concrete mixtures. Also a co-relation is developed between the concrete strength structures and concrete strength obtained by UPSV ${ }^{[2]}$. Domagai Damja Novie, et al obtained the corelation of mechanical characteristics of concrete measured by experimental testing of concrete specimens drilled from reinforced concrete columns which were a part of a dock for small ships and were under water for approximately 20 years. Applied experimental methods in order to assess the state and the quality of concrete are a combination of destructive and non-destructive methods. The UPV test was carried out on drilled specimens in laboratory. Destructive methods are determination of concrete compressive strength and modulus of elasticity on drilled specimens by compression test ${ }^{[3]}$.

Raffale Pucinotti, reported the influence of steel bars present in concrete on the propagation velocity of the ultrasonic waves. A series of experimental investigations have been conducted on simple concrete 300x300x500 mm specimen and 300x300x500 mm reinforced concrete specimens unlike each other for the longitudinal and transverse spaces of reinforcement. It is observed that transverse steel reinforcements (stirrups 
of $8 \mathrm{~mm} \mathrm{dia),} \mathrm{slightly} \mathrm{modifying} \mathrm{the} \mathrm{course} \mathrm{of} \mathrm{the} \mathrm{ultra-sonic} \mathrm{waves,} \mathrm{but} \mathrm{not} \mathrm{modify} \mathrm{significantly} \mathrm{its} \mathrm{velocity}{ }^{[4]}$. M.A. Saleem, in their research work evaluated five storied frame structure whose construction was stopped seven years ago. For evaluation purpose load test and core test were performed on four floors from basement to first floor. Test results indicated that the structure had adequate strength for future use even though the structure for unprotected for several years. It is also reviewed from the results that combination of test instead of performing one type of test, provide more suitable results to confidentially except or reject the structure ${ }^{[5]}$.

A. Zacoeb, et al in their project work they estimated a compressive strength of existing concrete structures by core test of diameter $100 \mathrm{~mm}$. The test results are obtained by using uniaxial compressive strength test as per JIS A1170. They conducted point load test to get an alternative solutions. The point load test is performed by taking drilled core specimens from ready mixed concrete with maximum coarse aggregate size $20 \mathrm{~mm}$ in architectural structures and $40 \mathrm{~mm}$ in Civil Engineering structures with concrete grade of 16 to 50 $\mathrm{MPa}$, the cores of diameter of $100 \mathrm{~mm}$ and $125 \mathrm{~mm}$ with $\mathrm{h} / \mathrm{d}$ ratio 2.0 is tested by using uniaxial compressive strength test and the core diameter of $35 \mathrm{~mm}$ and $50 \mathrm{~mm}$ with $\mathrm{h} / \mathrm{d}$ ratio 1.5 and 2.0 are tested by using point load test ${ }^{[6]}$. M.Yaqub, et al in their research work described the comparison of core strength and cube compressive strength of hardened concrete in existing structures. They extracted the cores from the hardened concrete of twelve years old building with two different core diameters and two different sizes of concrete cubes. The obtained compressive strength results were comparing and they found that the smaller size cores and cubes show greater strength as compared to larger size cores and concrete cubes ${ }^{[7]}$.

Ramesh Kumar G.B, in their work the NDT tests were performed on concrete structures. The structures are in extreme danger state before reaching their life span, because of the fact that the materials in the structure are exposed to severe environmental conditions. For that structure the repairing and rehabilitation is necessary. Before the danger zones in the structure are identified by visual appearance, proper investigations on strength of the structure. For this purpose various tests were performed such as Rebound hammer, carbonation test, ultrasonic pulse velocity, Rebar Locator test and Impact Echo test. From these test results the structures have adequate strength for future use ${ }^{[8]}$. Dr. V. Karthikeyan, et al in their paper analyzed the deficiencies in the construction of a multi storied RC frame structure. For analyses of strength of concrete elements of columns and slabs the Non-destructive tests were conducted. The core samples are extracted from the RC columns and slabs. The concrete core samples were then subjected to compressive strength test in compressive testing machine. Then the obtained cube strength results are compared with Is 456:2000. The codal provision shows that the slabs in ground, first and second floor in the concrete structure are had minimum strength of concrete grade M20. The $\mathrm{RC}$ columns in the ground, first and second floor are less than minimum concrete grade M20. From the obtained results it is necessary to prefer for suitable rehabilitation techniques to strengthen the RC columns in the concrete structure ${ }^{[9]}$. Bohdan stawiski, in their work assumed that the floor slabs or beam strength is same in all directions. By considering the load-bearing capacities of structural elements and techniques used in concrete structures the concrete is isotropic. The research work shows that strength of concrete in slabs along direction of concreting had a qualitative effect and also quantitative effects. The results show that the compressive strength of concrete in horizontal direction varies with thickness of slab ${ }^{[10]}$.

Kumavat H.R, et al in their paper case study evaluated the concrete quality of building age was 8 years. The various types of NDT tests were performed such as ultrasonic pulse velocity, half-cell potential, carbonation depth, rebar locator, cover meter and core sampling. The structures are failed due to temperature variations, physical causes and chemical attack due to environment. Then the Structure is investigated by visual observation and conducting NDT tests and field test, and they focused on standard testing procedure of NDT for accuracy of the result ${ }^{[11]}$.

Jedidi Malek, et al in their work to estimate a mechanical properties of concrete the destructive and Non-destructive tests were performed. In this report the crushing of samples is the destructive test and rebound hammer test and ultrasonic pulse velocities tests are non-destructive tests on prepared cylindrical specimens of size $16 \mathrm{~cm} \times 32 \mathrm{~cm}$ with varying the water/ cement ratio and the cement dosage. Then the compressive strength of concrete is determined at different ages (7, 14 and 28 days) the modulus of elasticity determined by pulse velocity test method. Finally they obtained results showed that the difference between the resistance values of destructive and non-destructive methods decreases with increasing age of concrete. The dynamic modulus of elasticity increases with the curing of concrete until the age of three months ${ }^{[12]}$.

Dr. Isam $\mathrm{H}$, et al obtained unified relationship between the results of in-situ hardened concrete and the results of cube crushing strength of concrete by using statistical methods carried on concrete cubes with different mixing ratio and different curing conditions and finding core relation curves to predict the strength of concrete much better. They have concluded that, there is a strong co-relation between compressive strength and rebound number, ultra-sonic pulse velocity (UPV) obtained from concrete cubes which indicated a good corelation coefficient. Using the above co-relation curve in-situ strength of concrete for any structural member can be determined by knowing rebound number and UPV of that structural member ${ }^{[13]}$. 


\subsection{Objectives of the project}

1) Co-relation between actual compressive strength of concrete cubes and strength estimated from the cores free from reinforcement.

2) Co-relation between actual compressive strength of concrete cubes and strength estimated from the cores with reinforcement.

3) Co-relation between actual compressive strength of concrete cubes and strength estimated from cores having different $\mathrm{h} / \mathrm{d}$ ratio without reinforcement

4) Co-relation between actual compressive strength of concrete cubes and strength estimated from cores having different $\mathrm{h} / \mathrm{d}$ ratio with reinforcement.

5) Co-relation between strength estimated from rebound hammer randomly and strength estimated from the cores free from reinforcement.

6) Co-relation between strength estimated from rebound hammer randomly and strength estimated from the cores with reinforcement.

\subsection{Cement}

\section{Materials Used}

Portland Pozzolonic cement (ultratech brand) conforming to IS 1489-1991 was used. The physical properties of cement used are shown in table1.

Table 1: Physical Properties of cement

\begin{tabular}{|c|l|c|}
\hline Sl. No & Properties & Chart results \\
\hline 1 & Specific gravity & 3.11 \\
\hline 2 & Fineness & $2.0 \%$ \\
\hline 3 & Normal Consistency & $33.0 \%$ \\
\hline 4 & Initial setting time & 34 minutes \\
\hline
\end{tabular}

\subsection{Fine Aggregates}

Locally available river sand, passing through $4.75 \mathrm{~mm}$ sieve and retained on 150 micron and free from impurities is used for the work. The tests were conducted as per IS 2386-1975 and result of sieve analysis and physical properties of fine aggregates are shown below.

Table 2: Sieve Analysis Results of Fine Aggregates

\begin{tabular}{|c|c|c|}
\hline Sl. No. & IS Sieve Size & Cumulative \% passing \\
\hline 1 & $10 \mathrm{~mm}$ & 100 \\
\hline 2 & $4.75 \mathrm{~mm}$ & 97 \\
\hline 3 & $2.36 \mathrm{~mm}$ & 92.4 \\
\hline 4 & $1.18 \mathrm{~mm}$ & 69.2 \\
\hline 5 & 600 micron & 39.8 \\
\hline 6 & 300 micron & 3.4 \\
\hline 7 & 150 micron & 0.02 \\
\hline 8 & pan & 00 \\
\hline
\end{tabular}

Table 3: Physical Properties of Fine Aggregate

\subsection{Coarse aggregate}

\begin{tabular}{|c|c|}
\hline Specific gravity & 2.416 \\
\hline Water absorption & $2.04 \%$ \\
\hline Bulk density & $1720 \mathrm{Kg} / \mathrm{m}^{3}$ \\
\hline
\end{tabular}

Crushed stone of $20 \mathrm{~mm}$ down size and $12.5 \mathrm{~mm}$ were used in this present work. The sieve analysis result and physical properties of coarse aggregate of $20 \mathrm{~mm}$ down and $12.5 \mathrm{~mm}$ size are shown in following tables.

Table 4: Sieve Analysis Results of Coarse Aggregate

\begin{tabular}{|c|c|c|c|}
\hline \multirow[t]{2}{*}{ Sl.No } & \multirow[t]{2}{*}{ IS Sieve size } & \multicolumn{2}{|c|}{ Cumulative \% passing } \\
\hline & & $20 \mathrm{~mm}$ & $12.5 \mathrm{~mm}$ \\
\hline 1 & $40 \mathrm{~mm}$ & 100 & 100 \\
\hline 2 & $20 \mathrm{~mm}$ & 61.62 & 100 \\
\hline 3 & $12.5 \mathrm{~mm}$ & 3.04 & 96.7 \\
\hline 4 & $10 \mathrm{~mm}$ & 1.02 & 88.89 \\
\hline 5 & 4.75 & 0.01 & 2.03 \\
\hline 6 & pan & 00 & 00 \\
\hline
\end{tabular}

Table 5: Physical Properties of Coarse Aggregate

\begin{tabular}{|l|c|c|}
\hline Size of aggregate & $\mathbf{2 0} \mathbf{~ m m}$ & $\mathbf{1 2 . 5} \mathbf{~ m m}$ \\
\hline specific gravity & 2.773 & 2.8 \\
\hline water absorption & $1.5 \%$ & 2.53 \\
\hline bulk density & $1570 \mathrm{~kg} / \mathrm{m}^{3}$ & $1562 \mathrm{~kg} / \mathrm{m}^{3}$ \\
\hline
\end{tabular}




\subsection{Mix Design}

Using the physical properties of cement, fine aggregate and coarse aggregate concrete mix was designed for M20 grade concrete. The concrete mix is designed as per IS 10262:2009 for the M-20 Grade of concrete for two different water-cement ratios such as 0.55 and 0.53 .The mix proportions are presented in following table ${ }^{[14]}$.

Table 6: Mix proportions

\begin{tabular}{|c|c|c|c|}
\hline Water-cement ratio & $\begin{array}{c}\text { Cement } \\
\left(\mathbf{K g} / \mathbf{m}^{\mathbf{3}}\right)\end{array}$ & $\begin{array}{c}\text { Fine aggregate } \\
\left(\mathbf{K g} / \mathbf{m}^{\mathbf{3}}\right)\end{array}$ & $\begin{array}{c}\text { Coarse aggregate } \\
\left(\mathbf{K g} / \mathbf{m}^{\mathbf{3}}\right)\end{array}$ \\
\hline 0.53 & 361.47 & 678.78 & 1150.83 \\
\hline 0.55 & 348.32 & 689.42 & 1149.79 \\
\hline
\end{tabular}

\subsection{Trial mixes}

The concrete cubes of size $150 \mathrm{~mm} \times 150 \mathrm{~mm} \times 150 \mathrm{~mm}$, totally ten concrete cubes were cast for determination of compressive strength. Five cubes were prepared for water-cement ratio 0.53 and five cubes for water-cement ratio 0.55 . The concrete cubes were cured for 7 days in water pond. The cubes were tested in a compression testing machine, load at which the cube specimen ultimately fails is noted. The compressive strength is calculated by dividing the load by area of specimen. The obtained test results are represented in the following table ${ }^{[15]}$.

Table 7: Results of trial mix

\begin{tabular}{|c|l|l|l|c|}
\hline & \multicolumn{2}{|c|}{ W/C =0.53 } & \multicolumn{2}{c|}{ W/C=0.55 } \\
\hline $\begin{array}{c}\text { Specim } \\
\text { en No. }\end{array}$ & $\begin{array}{l}\text { Load } \\
(\mathbf{K g})\end{array}$ & $\begin{array}{l}\text { Compressive strength } \\
\left(\mathbf{N} / \mathbf{m m}^{2}\right)\end{array}$ & $\begin{array}{l}\text { Load } \\
(\mathbf{K g})\end{array}$ & $\begin{array}{l}\text { Compressive } \\
\text { strength }\left(\mathbf{N} / \mathbf{m m}^{2}\right)\end{array}$ \\
\hline 1 & 56000 & 24.416 & 49000 & 21.364 \\
\hline 2 & 57000 & 24.852 & 50000 & 21.80 \\
\hline 3 & 56000 & 24.416 & 50000 & 21.80 \\
\hline 4 & 55000 & 23.98 & 49000 & 21.364 \\
\hline 5 & 56000 & 24.416 & 49000 & 21.364 \\
\hline
\end{tabular}

From the above table it is observed that $\mathrm{W} / \mathrm{C}=0.55$ resulted in satisfactory compressive strength for $\mathrm{M}-20$ grade of concrete at the age of 7 days. Therefore $\mathrm{W} / \mathrm{C}=0.55$ is finalized for further casting work.

Table 8: Mix proportions of W/C 0.55

\begin{tabular}{|c|c|c|c|c|}
\hline $\begin{array}{c}\text { Water- } \\
\text { cement } \\
\text { ratio }\end{array}$ & $\begin{array}{c}\text { Cement } \\
\left(\mathbf{K g} / \mathbf{m}^{\mathbf{3}}\right)\end{array}$ & $\begin{array}{c}\text { Fine } \\
\text { aggregate } \\
\left(\mathbf{K g} / \mathbf{m}^{\mathbf{3}}\right)\end{array}$ & $\begin{array}{c}\text { Coarse } \\
\text { aggregate } \\
\left(\mathbf{K g} / \mathbf{m}^{\mathbf{3}}\right)\end{array}$ & $\begin{array}{c}\text { Average compressive } \\
\text { strength } \\
\left(\mathbf{N} / \mathbf{m m}^{\mathbf{2}}\right)\end{array}$ \\
\hline 0.55 & 348.32 & 689.42 & 1149.79 & 21.53 \\
\hline
\end{tabular}

\subsection{Casting}

\subsubsection{Destructive Test:}

2.6.1.1 Cubes: The twelve numbers of cubes of size $150 \mathrm{mmx} 150 \mathrm{mmx} 150 \mathrm{~mm}$ were cast. Six numbers of cubes are used for the cube compression test and other six numbers of cubes are used for the rebound hammer testing.

2.6.1.2 Non Destructive Test:

2.6.1.2.1 Slabs: The slabs are designed as per codal provision IS456:2000. The five numbers of slabs were cast of size $500 \mathrm{~mm} \times 500 \mathrm{~mm}$ with $120 \mathrm{~mm}$ thickness is provided ${ }^{[15]}$.

Table 9: Details of Slab Dimensions

\begin{tabular}{|c|c|c|c|c|}
\hline $\begin{array}{l}\text { Particu } \\
\text { lars }\end{array}$ & $\begin{array}{l}\text { Dimension } \\
(\mathrm{mm})\end{array}$ & $\begin{array}{c}\text { Clear } \\
\text { cover }(\mathbf{m m})\end{array}$ & Reinforcement details & remark \\
\hline Slab & $\begin{array}{l}500 \times 500 \times 1 \\
20\end{array}$ & 25 & $\begin{array}{c}\text { \#10@150 c/c (main)\#8@150c/c } \\
\text { (distribution) }\end{array}$ & Two way slab \\
\hline
\end{tabular}

\subsection{Curing:}

The cast concrete cubes and slab elements demoulded after 24 hours and kept in water tank for 28 days curing. After that the specimens were tested in a laboratory.

\subsection{DESTRUCTIVE TEST}

\section{Testing}

\subsubsection{Cube compression test:}

The cube specimens are used for determining characteristic compressive strength. The cubes are tested in a compression testing machine of capacity $2000 \mathrm{KN}$. The load is applied in such a way that, the two opposite side of the cubes are compressed (top and bottom surface). The load at which cube specimen ultimately fails is noted. The compressive strength is calculated by dividing the load by area of specimen and determination of compressive strength were performed as per IS:516-1959. Totally five numbers of concrete cubes are tested. The calculated compressive strength of concrete cubes are represented in following table. 
Table 10: Results of Cube Compression Test

\begin{tabular}{|c|c|c|c|}
\hline Sl. No & $\begin{array}{c}\text { Cube } \\
\text { Number }\end{array}$ & $\begin{array}{c}\text { Load } \\
(\mathbf{K g})\end{array}$ & $\begin{array}{l}\text { Compressive strength } \\
\left(\mathbf{N} / \mathbf{m m}^{\mathbf{2}}\right)\end{array}$ \\
\hline 1 & C-1 & 72000 & 31.40 \\
\hline 2 & C-2 & 75000 & 32.71 \\
\hline 3 & C-3 & 73000 & 31.84 \\
\hline 4 & C-4 & 74000 & 32.27 \\
\hline 5 & C-5 & 73000 & 31.84 \\
\hline
\end{tabular}

\subsection{NON DESTRUCTIVE TEST}

\subsubsection{Schmidt Rebound Hammer Test}

\subsubsection{Principle:}

The principle of this method is rebound of an elastic mass depends on the hardness of the surface against which mass Strikes. The plunger of hammer is pressed strongly and steadily against the concrete surface at right angles to its surface until the spring loaded mass is triggered from the locked position. The distance travelled by the mass as a percentage is derived as rebound number. A low rebound number will indicate that the surface of the concrete is soft and the concrete weak. A high rebound number will indicate that the concrete is hard and strong.

\subsubsection{Concrete cubes:}

Testing of concrete cubes using rebound hammer is such that the cubes were placed and loaded in the UTM at $40 \mathrm{KN}$ and with this holded axial load rebound hammer readings are taken for the five concrete cubes with horizontal orientation of hammer. The obtained rebound numbers and equivalent cube compressive strength of concrete cubes obtained from strength conversion chart are represented in the following table.

Table 11: Rebound Hammer Results of Concrete Cubes

\begin{tabular}{|c|c|c|c|}
\hline $\begin{array}{c}\text { SI. } \\
\text { No. }\end{array}$ & $\begin{array}{c}\text { Cube } \\
\text { Number }\end{array}$ & $\begin{array}{c}\text { Rebound } \\
\text { number }\end{array}$ & $\begin{array}{c}\text { Equivalent cube Compressive strength } \\
\left(\mathbf{N} / \mathbf{m m}^{\mathbf{2}} \mathbf{)}\right.\end{array}$ \\
\hline 1 & C-1 & 27 & 20.4 \\
\hline 2 & C- 2 & 29.2 & 24 \\
\hline 3 & C-3 & 29 & 23.6 \\
\hline 4 & C-4 & 27.8 & 21.5 \\
\hline 5 & C-5 & 29 & 23.5 \\
\hline
\end{tabular}

\subsubsection{Slab:}

For each cast structural slab elements markings were made at free from reinforcement (only concrete portion), and along main reinforcement. The rebound numbers were taken randomly from the three numbers of slabs and totally twelve readings are taken at different places in the slab elements with vertical orientation of rebound hammer. Average rebound numbers and equivalent cube compressive strength are presented in table 12.

Table 12: Rebound Hammer Results of Slabs

\begin{tabular}{|c|c|c|c|}
\hline Sl. No. & $\begin{array}{c}\text { Slab } \\
\text { Number }\end{array}$ & $\begin{array}{c}\text { Rebound } \\
\text { number }\end{array}$ & $\begin{array}{c}\text { Equivalent cube } \\
\text { Compressive strength } \\
\left(\mathbf{N} / \mathbf{m m}^{2}\right)\end{array}$ \\
\hline 1 & S-1 & 35 & 39 \\
\hline 2 & S-2 & 36 & 41 \\
\hline 3 & S-3 & 32.5 & 34.5 \\
\hline 4 & S-4 & 34.5 & 38 \\
\hline 5 & S-5 & 33 & 35 \\
\hline
\end{tabular}

\subsection{2) Core testing:}

\subsubsection{Principle:}

In this method concrete cores of size ranging from $20 \mathrm{~mm}$ to $150 \mathrm{~mm}$ in diameter and $50 \mathrm{~mm}$ to 500 $\mathrm{mm}$ long are drilled out by diamond cutters. The recommended diameters are 100 to $150 \mathrm{~mm}$, but if the drill depth is insufficient as in the case of slabs, then smaller diameter may be used but not less than three times nominal aggregate size. The core diameter to length ratio shall be normally between 1.0 to 2.0. At least three cores shall be tested for acceptable accuracy. The cores were take in the location free from reinforcement and along the reinforcement at each location fifteen numbers of cores were taken ${ }^{[13]}$.

\subsubsection{Selection of core size:}

We are taking cores from the cast slab of thickness $120 \mathrm{~mm}$. therefore in the present case it is decided to take cores of diameter $50 \mathrm{~mm}$. the height to diameter ratio were varied from 1.5, 1.75 and 2.0. For each H/D ratio five cores were taken. Therefore, result is average of five numbers. 


\subsubsection{Core drilling:}

The cores were cut by means of a rotary cutting tool with diamond bits size $50 \mathrm{~mm}$. The core cutting equipment is heavy and it is firmly supported and braced against the concrete surface to prevent relative movement which will result in a distorted or broken core, a continuous water supply is provided to lubricate the core cutter. By applying the uniform pressure in a vertical direction, totally thirty numbers of cores were extracted from the marked concrete slabs. In that fifteen numbers of cores are extracted from only in concrete portion (without reinforcement) and other fifteen numbers of cores are extracted with reinforcement.

\subsubsection{Visual inspection:}

The drilled cores from the slab elements were observed, the aggregates are equally distributed and there is no cracks and damage caused to the drilled cores.

\subsubsection{End preparation:}

The drilled cores are marked at suitable heights and diameter. The marked cores are trimmed with three different height/diameter ratios such as $1.50,1.75$ and 2.0. The trimmings of cores were done by water lubricated diamond saw. The end surfaces of the trimmed cores were smoothened for compression test.

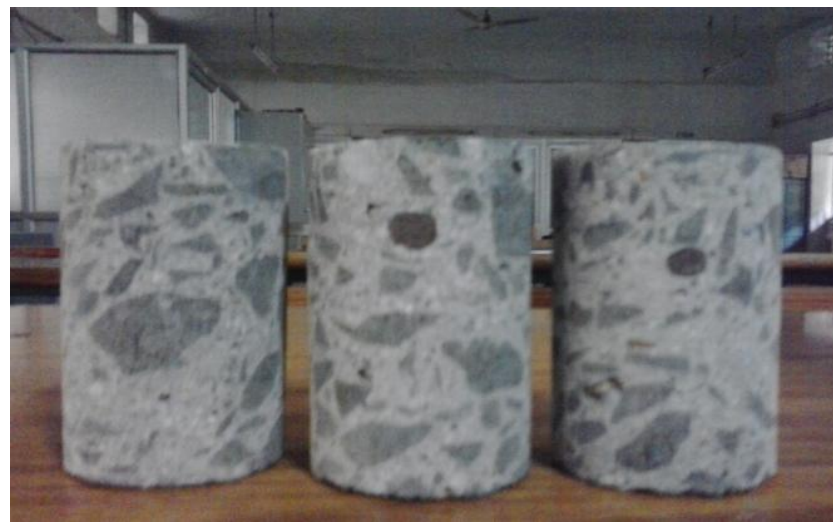

A) H/D RATIO 1.5

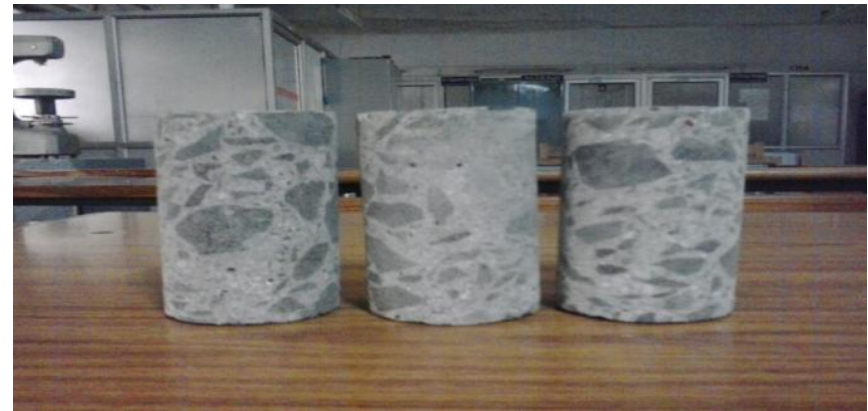

B) H/D RATIO 1.75

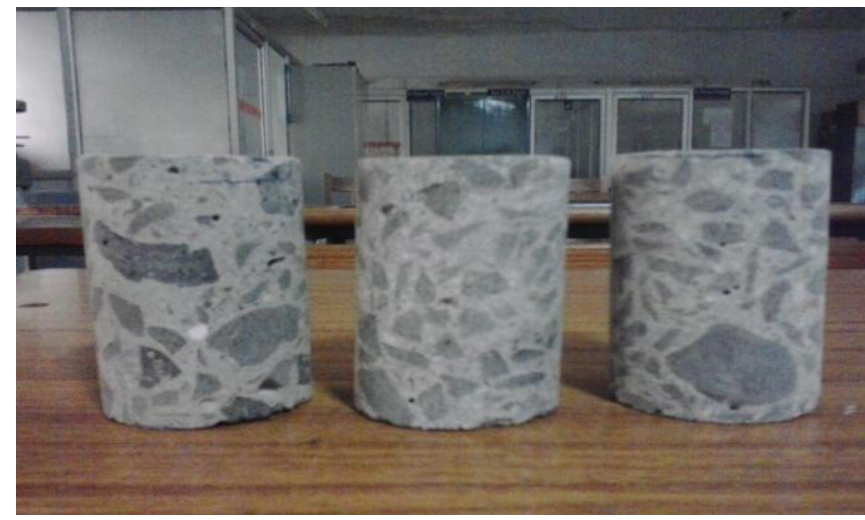

C) H/D RATIO 2.0

Fig.1 Core Specimens after Trimming 


\subsubsection{Density Determination:}

The density and excess voidage is determined for the trimmed cores of H/D ratio 1.50, 1.75 and 2.0 The density and excess voidage were determined by using following formula.

$\mathrm{D}_{\mathrm{a}}=\underline{\mathrm{W}}_{\underline{\mathrm{t}}}-\mathrm{D}_{\underline{\mathrm{c}}}\left(\mathrm{V}_{\mathrm{t}}-\mathrm{V}_{\underline{\mathrm{u}}}\right)-\mathrm{W}_{\underline{\mathrm{S}}} /\left(\mathrm{Vu}-\mathrm{V}_{\mathrm{s}}\right)$

Where, $\mathrm{V}_{\mathrm{u}}=$ volume of trimmed core

Dc=density of capping materials

$\mathrm{Wt}=$ Weight of soaked / surface dry capped core in air and water.

$\mathrm{Vt}=$ Volume of soaked / surface dry capped core

Table 13: Density of Cores

\begin{tabular}{|c|c|c|}
\hline Sl.No & H/D ratio & Density $\left(\mathbf{K g} / \mathbf{m}^{3}\right)$ \\
\hline 1 & 1.50 & 2518.81 \\
\hline 2 & 1.75 & 2495.65 \\
\hline 3 & 2.0 & 2496.29 \\
\hline
\end{tabular}

\subsubsection{Core test:}

The cores were extracted from cast slab by using the core cutting machine with diamond bit size $50 \mathrm{~mm}$. totally thirty numbers of cores were extracted in the location free from reinforcement and along the reinforcement, at each location fifteen numbers of cores were taken. The extracted cores were trimmed to make the ends smooth, with three different H/D ratios such as 1.50, 1.75 and 2.0. After that concrete cores were tested in UTM at the rate of $12-24 \mathrm{~N} /\left(\mathrm{mm}^{2} . \mathrm{min}\right)$, and the load at which core specimen fails is noted. The measured core strength of cores is calculated by dividing the load by the area of cylindrical core specimen ${ }^{[16]}$.

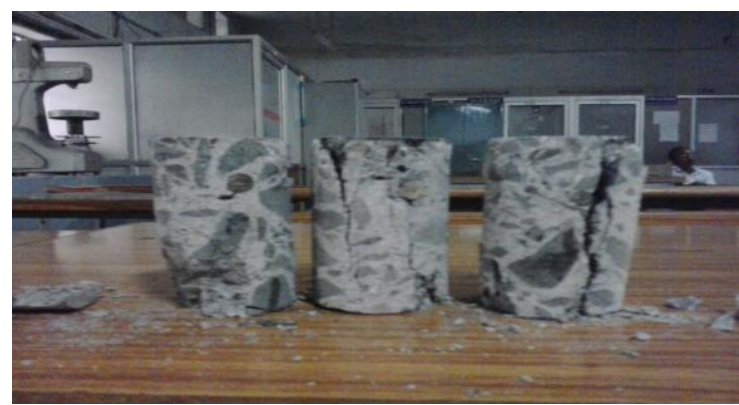

A) H/D RATIO 1.5

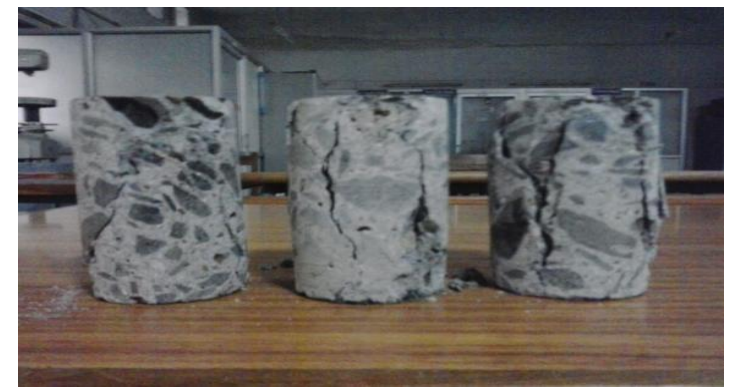

B) H/D RATIO 1.75

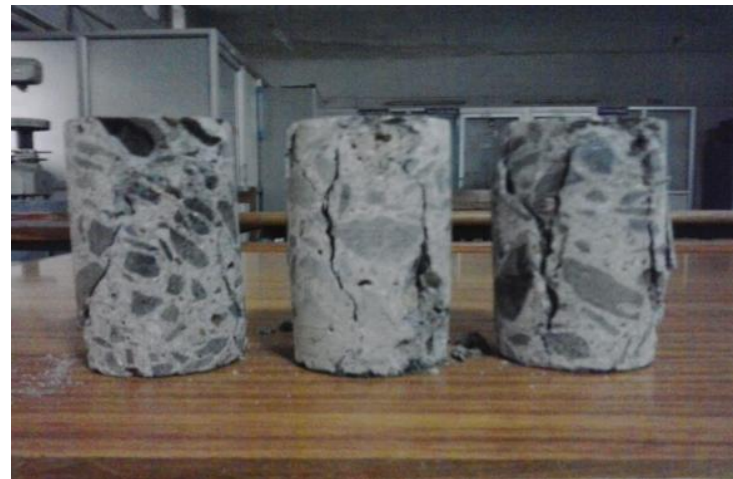

C) H/D RATIO 2.0

Fig. 2 Core Specimens after Testing 


\section{IIII. Results And Discussion}

The obtained measured core compressive strength results of cores with H/D ratio 1.5, 1.75 and 2.0 are represented in the following tables.

4.1 Measured Core Compressive Strength Results

4.1.1 Cores Free From Reinforcement

Table 14 : Measured Core Compressive Strength Results Of Differenet H/D Ratio

\begin{tabular}{|c|c|c|c|c|c|c|}
\hline Sl.no. & \multicolumn{2}{|c|}{$\mathrm{H} / \mathrm{D}=1.50$} & \multicolumn{2}{|c|}{$\mathrm{H} / \mathrm{D}=1.75$} & \multicolumn{2}{|r|}{$\mathrm{H} / \mathrm{D}=2.0$} \\
\hline & $\begin{array}{c}\text { Failure } \\
\text { load (ton) }\end{array}$ & $\begin{array}{c}\text { Measured core } \\
\text { compressive } \\
\text { strength }\left(\mathrm{N} / \mathrm{mm}^{2}\right)\end{array}$ & $\begin{array}{c}\text { Failure } \\
\text { load (ton) }\end{array}$ & $\begin{array}{c}\text { Measured core } \\
\text { compressive } \\
\text { strength }\left(\mathbf{N} / \mathbf{m m}^{2}\right)\end{array}$ & $\begin{array}{l}\text { Failure load } \\
\text { (ton) }\end{array}$ & $\begin{array}{c}\text { Measured core } \\
\text { compressive strength } \\
\left(\mathrm{N} / \mathbf{m m}^{2}\right)\end{array}$ \\
\hline 1 & 2.80 & 18.07 & 3.75 & 24.21 & 3.00 & 19.36 \\
\hline 2 & 2.85 & 18.40 & 3.00 & 19.36 & 3.25 & 20.98 \\
\hline 3 & 2.80 & 18.07 & 3.35 & 20.98 & 3.25 & 20.98 \\
\hline 4 & 2.90 & 18.72 & 3.10 & 20.01 & 3.30 & 21.30 \\
\hline 5 & 2.83 & 18.27 & 3.20 & 21.30 & 3.20 & 20.66 \\
\hline
\end{tabular}

\subsubsection{Cores with Reinforcement}

Table 15 : Measured Core Compressive Strength Results Of Differenet H/D Ratio

\begin{tabular}{|c|c|c|c|c|c|c|}
\hline \multirow[t]{2}{*}{ Sl.no. } & \multicolumn{2}{|c|}{$H / D=1.50$} & \multicolumn{2}{|c|}{$\mathrm{H} / \mathrm{D}=1.75$} & \multicolumn{2}{|r|}{$H / D=2.0$} \\
\hline & $\begin{array}{l}\text { Failure load } \\
\text { (ton) }\end{array}$ & $\begin{array}{c}\text { Measured core } \\
\text { compressive } \\
\text { strength }\left(\mathbf{N} / \mathbf{m m}^{2}\right)\end{array}$ & $\begin{array}{l}\text { Failure load } \\
\text { (ton) }\end{array}$ & $\begin{array}{c}\text { Measured core } \\
\text { compressive } \\
\text { strength }\left(\mathbf{N} / \mathbf{m m}^{2}\right)\end{array}$ & $\begin{array}{l}\text { Failure load } \\
\text { (ton) }\end{array}$ & $\begin{array}{c}\text { Measured core } \\
\text { compressive strength } \\
\left(\mathrm{N} / \mathbf{m m}^{2}\right)\end{array}$ \\
\hline 1 & 3.20 & 20.66 & 4.40 & 28.40 & 5.50 & 35.50 \\
\hline 2 & 3.25 & 20.98 & 4.00 & 25.82 & 5.00 & 32.28 \\
\hline 3 & 3.30 & 21.30 & 4.50 & 29.05 & 5.25 & 33.89 \\
\hline 4 & 3.30 & 21.30 & 4.20 & 27.11 & 5.20 & 33.57 \\
\hline 5 & 3.28 & 21.17 & 4.45 & 28.73 & 5.30 & 34.21 \\
\hline
\end{tabular}

\subsection{Corrections For Measured Core Compressive Strength}

The corrections are applied to the measured core compresive strength. Corrections due to excess voidage and effect fof H/D ratio are to be applied.

\subsubsection{Correction Due To Excess Voidage}

Table 16: Excess Voidage Correction Factors

\begin{tabular}{|c|c|c|c|}
\hline $\begin{array}{c}\text { Sl. } \\
\text { No. }\end{array}$ & $\begin{array}{c}\mathbf{( H / D )} \\
\text { ratio }\end{array}$ & $\begin{array}{l}\text { Estimated } \\
\text { voidage }\end{array} \mathbf{( \% )}^{\text {excess }}$ & $\begin{array}{l}\text { Excess voidage } \\
\text { correction factors }\end{array}$ \\
\hline 1 & 1.50 & 1.177 & 1.09 \\
\hline 2 & 1.75 & 1.14 & 1.08 \\
\hline 3 & 2.0 & 1.115 & 1.065 \\
\hline
\end{tabular}

The excess voidage correction factors are represented in the above table. By applying these correction factors the corrected core compressive strength was obtained and represented in the folowing tables.

\subsubsection{Cores Free From Reinforcement}

Table 17: Corrected Core Compressive Strength with H/D Ratio 1.50, 1.75 and $2.0\left(\mathrm{~N} / \mathrm{mm}^{2}\right)$

\begin{tabular}{|c|c|c|c|}
\hline Sl.no. & $\mathbf{H} / \mathbf{D = 1 . 5 0}$ & $\mathbf{H} / \mathbf{D}=\mathbf{1 . 7 5}$ & $\mathbf{H} / \mathbf{D = 2 . 0}$ \\
\hline 1 & 19.69 & 26.41 & 20.61 \\
\hline 2 & 20.05 & 20.90 & 22.34 \\
\hline 3 & 19.69 & 22.65 & 22.34 \\
\hline 4 & 20.40 & 21.61 & 22.68 \\
\hline 5 & 19.91 & 23.00 & 22.00 \\
\hline
\end{tabular}

\subsubsection{Cores With Reinforcement}

Table 18: Corrected Core Compressive Strength with H/D Ratio 1.50, 1.75 and $2.0\left(\mathrm{~N} / \mathrm{mm}^{2}\right)$

\begin{tabular}{|c|c|c|c|}
\hline Sl.no. & H/D=1.50 & H/D=1.75 & H/D=2.0 \\
\hline 1 & 22.51 & 30.67 & 37.81 \\
\hline 2 & 22.86 & 27.88 & 34.37 \\
\hline 3 & 23.21 & 31.37 & 36.09 \\
\hline 4 & 23.21 & 29.27 & 35.75 \\
\hline 5 & 23.07 & 31.02 & 36.43 \\
\hline
\end{tabular}




\subsubsection{Corrections for height/ diameter ratio:}

Table 19: H/D Ratio Correction Factors

\begin{tabular}{|c|c|c|}
\hline Sl. No. & (H/D) ratio & ASTM C-42-90 \\
\hline 1 & 1.50 & 0.96 \\
\hline 2 & 1.75 & 0.98 \\
\hline 3 & 2.0 & 1.0 \\
\hline
\end{tabular}

using the above corection factor the corrected core compressive strength obtained and represented in the following tables.

\subsubsection{Cores Free From Reinforcement}

Table 20: Corrected Core Compressive Strength with H/D Ratio 1.50, 1.75 and $2.0\left(\mathrm{~N} / \mathrm{mm}^{2}\right)$

\begin{tabular}{|c|c|c|c|}
\hline Sl.no. & H/D=1.50 & H/D=1.75 & H/D=2.0 \\
\hline 1 & 18.90 & 25.61 & 20.61 \\
\hline 2 & 19.25 & 20.49 & 22.34 \\
\hline 3 & 18.90 & 22.20 & 22.34 \\
\hline 4 & 19.59 & 21.18 & 22.68 \\
\hline 5 & 19.10 & 22.54 & 22.00 \\
\hline
\end{tabular}

\subsubsection{Cores With Reinforcement}

Table 21: Corrected Core Compressive Strength with H/D Ratio 1.50, 1.75 and $2.0\left(\mathrm{~N} / \mathrm{mm}^{2}\right)$

\begin{tabular}{|c|c|c|c|}
\hline Sl.no. & H/D=1.50 & H/D=1.75 & H/D=2.0 \\
\hline 1 & 21.61 & 30.05 & 37.81 \\
\hline 2 & 21.95 & 27.32 & 34.37 \\
\hline 3 & 22.28 & 30.75 & 36.09 \\
\hline 4 & 22.30 & 28.70 & 35.75 \\
\hline 5 & 22.16 & 30.40 & 36.43 \\
\hline
\end{tabular}

4.3 Estimation of cube compressive strength from core strength:

The estimated cube compressive strength of concrete cores of H/D ratio 1.50, 1.75 and 2.0 were calculated by using the following relations.

\subsubsection{Core free from reinforcement:}

a) Horizontally drilled core:

Estimated cube strength $=\left(2.5 \mathrm{f}_{\lambda}\right) / 1.5+(1 / \lambda)$

b) Vertically drilled core:

Estimated cube strength $=\left(2.3 \mathrm{f}_{\lambda}\right) / 1.5+(1 / \lambda)$

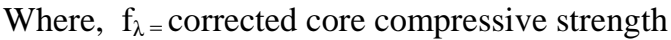

The obtained estimated cube compressive strength results of cores with H/D ratio $1.50,1.75$ and 2.0 are presented in the following tables.

Table 22: Estimated Cube Compressive Strength from core with H/D Ratio 1.50, 1.75 and $2.0\left(\mathrm{~N} / \mathrm{mm}^{2}\right)$

\begin{tabular}{|c|c|c|c|}
\hline Sl.no. & H/D=1.50 & H/D=1.75 & H/D=2.0 \\
\hline 1 & 20.70 & 28.440 & 23.70 \\
\hline 2 & 20.440 & 22.765 & 25.690 \\
\hline 3 & 20.070 & 24.660 & 25.690 \\
\hline 4 & 20.80 & 23.50 & 26.090 \\
\hline 5 & 20.30 & 25.030 & 25.300 \\
\hline
\end{tabular}

\subsubsection{Core with reinforcement (correction for reinforcement):}

Corrected core strength $=$ measured strength $\mathrm{x}\left[1.0+1.5\left(\oint_{1} / \dot{\emptyset}_{\mathrm{c}}\right) .(\mathrm{h} / \mathrm{l})\right]$

Where $\mathscr{\emptyset}_{\mathrm{l}}=$ bar diameter

$\dot{\emptyset}_{\mathrm{c}}=$ core diameter

$\mathrm{h}=$ distance of bar axis from nearer end of core

$1=$ core length

The obtained estimated cube compressive strength results of cores with H/D ratio $1.50,1.75$ and 2.0 are presented in the following tables. 
Table 23: Estimated Cube Compressive Strength from core with H/D Ratio 1.50, 1.75 and $2.0\left(\mathrm{~N} / \mathrm{mm}^{2}\right)$

\begin{tabular}{|c|c|c|c|}
\hline Sl.no. & H/D=1.50 & H/D=1.75 & H/D=2.0 \\
\hline 1 & 23.220 & 32.390 & 39.870 \\
\hline 2 & 23.580 & 29.340 & 35.410 \\
\hline 3 & 23.890 & 33.130 & 37.180 \\
\hline 4 & 23.950 & 30.920 & 37.700 \\
\hline 5 & 23.800 & 32.750 & 37.530 \\
\hline
\end{tabular}

1) Cores free from reinforcement

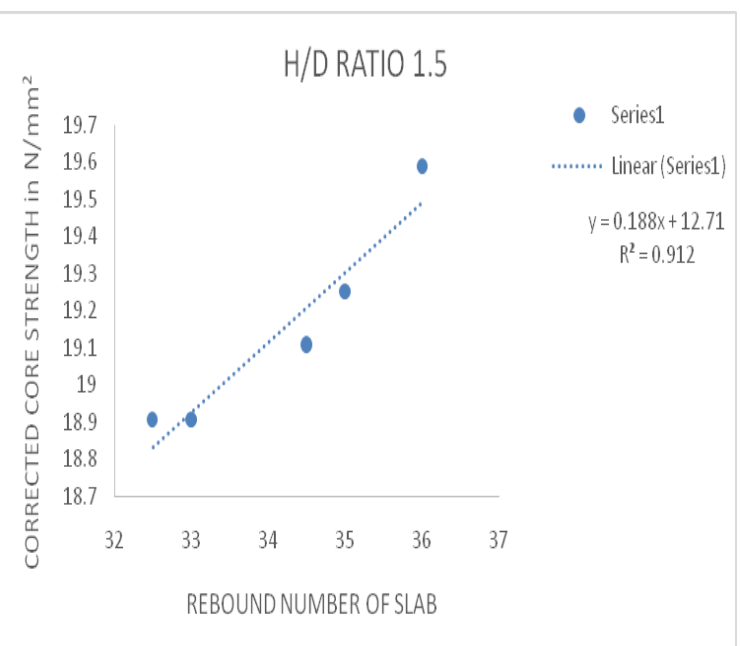

Fig.3 correlation between corrected core strength and rebound number of slab

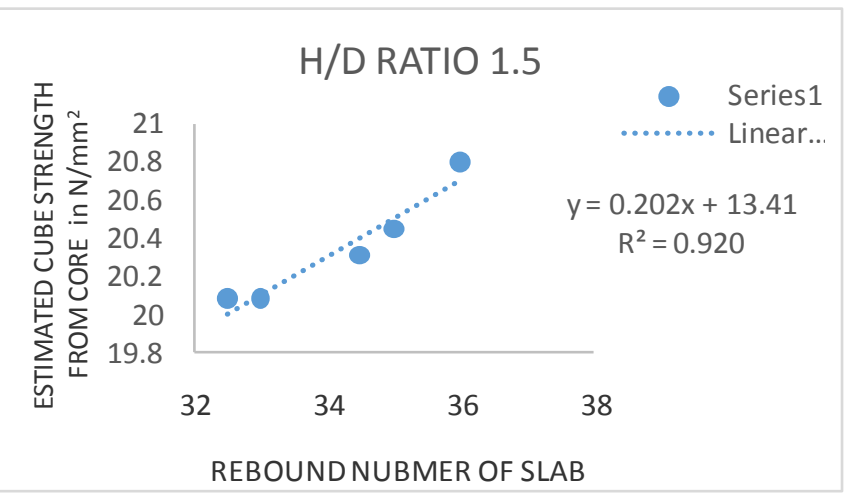

Fig.4 correlation between estimated cube strength from core and rebound number of slab

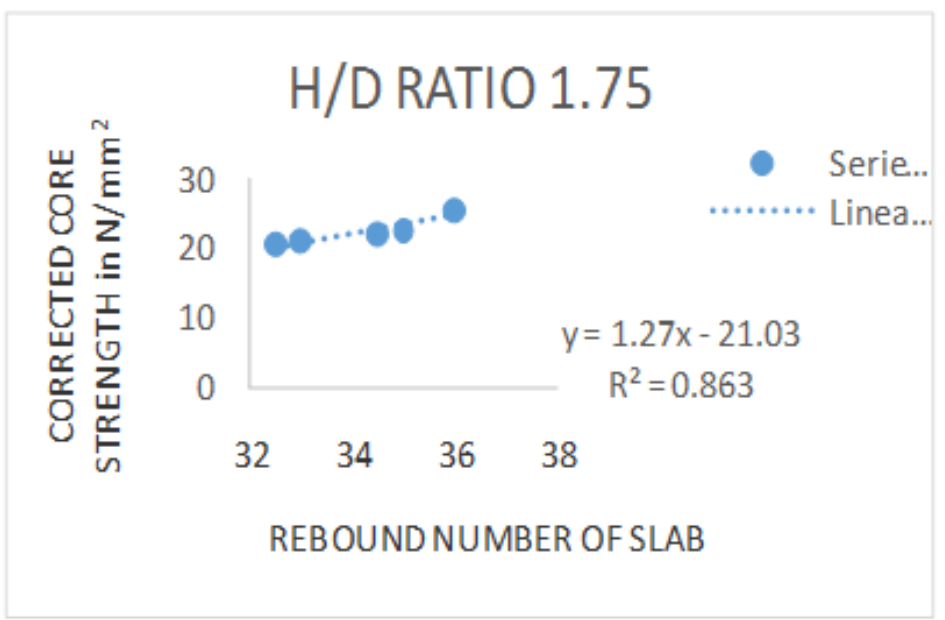

Fig.5 correlation between corrected core strength and rebound number of slab 


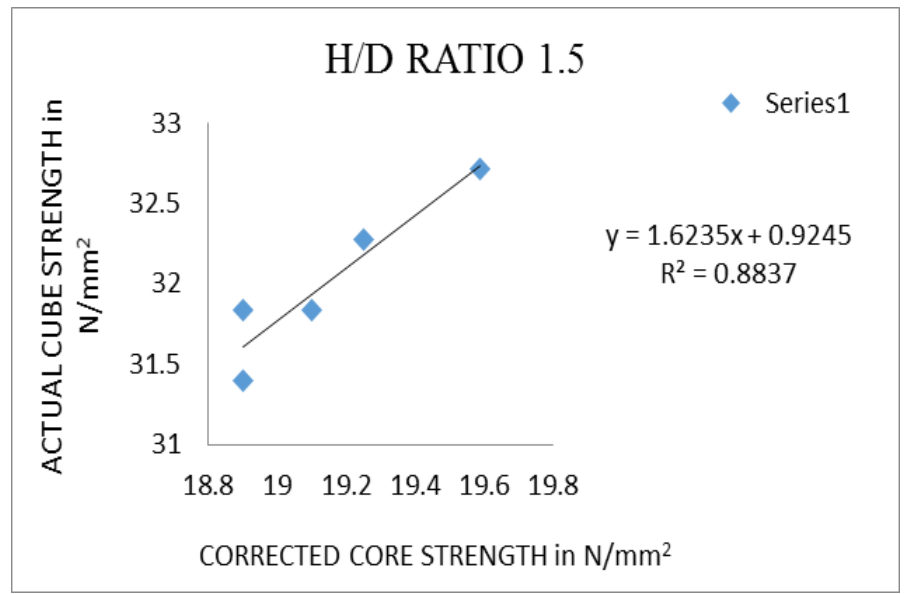

Fig.6 correlation between estimated cube strength from core and rebound number of slab

H/D RATIO 1.75

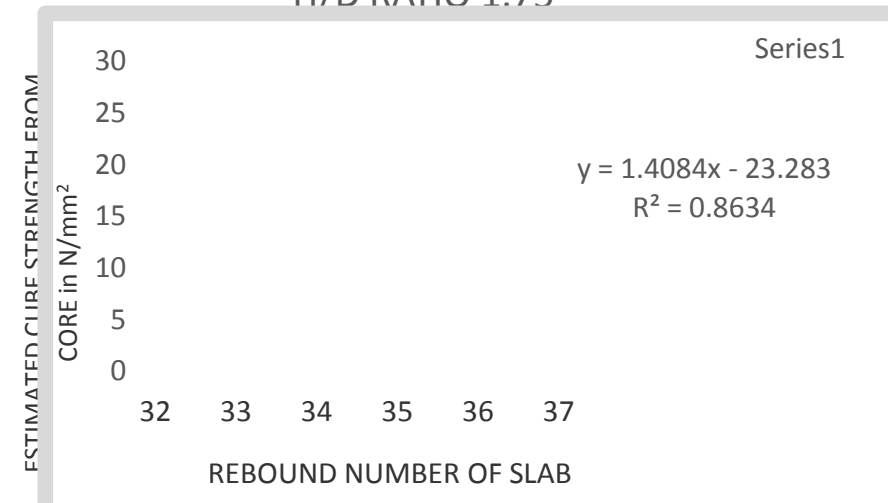

Fig.7 correlation between corrected core strength and rebound number of slab

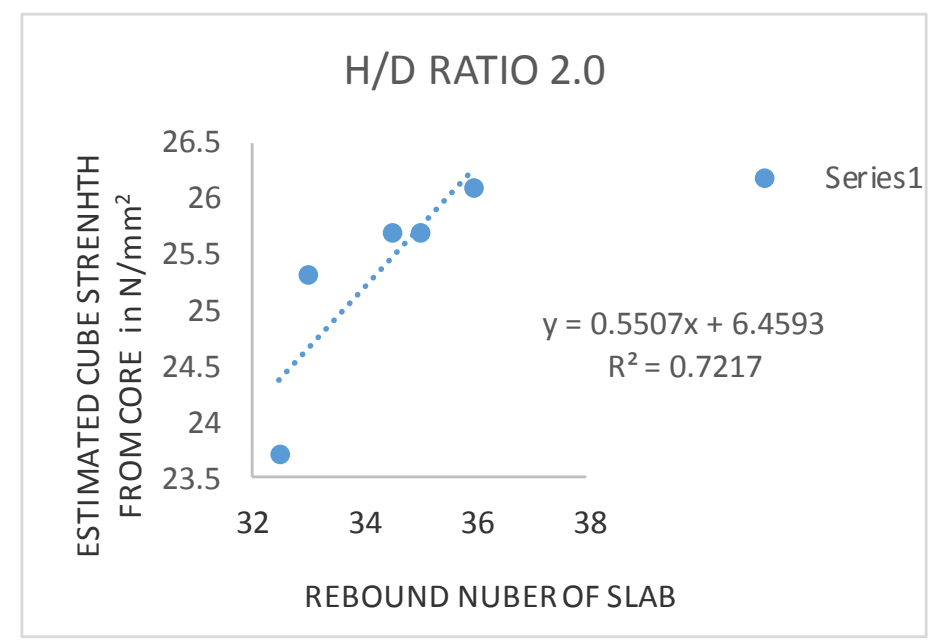

Fig.8 correlation between estimated cube strength from core and rebound number of slab 


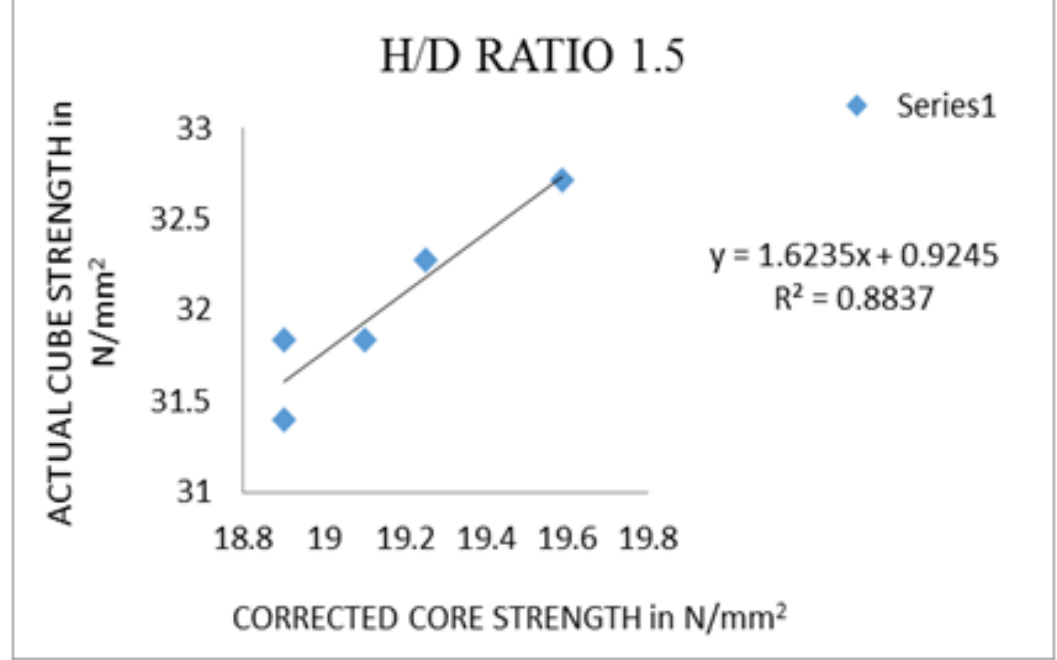

Fig.9 Correlation between actual cube strength and corrected core strength

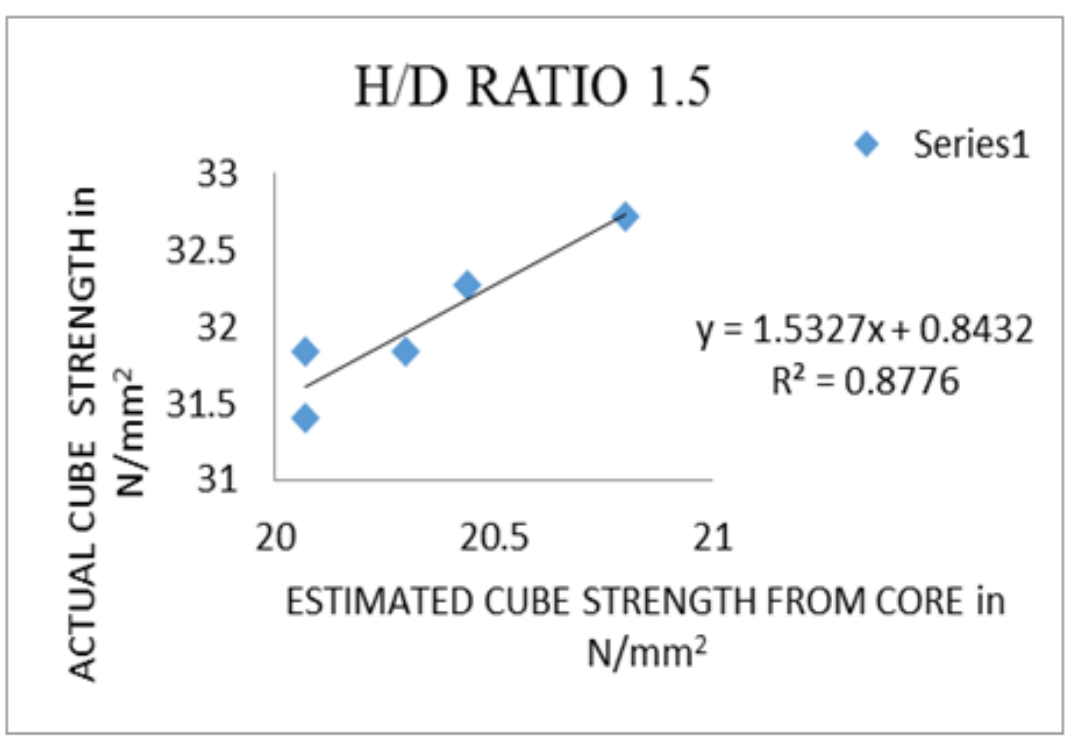

Fig.10 correlation between actual cube strength and core estimated cube strength from core

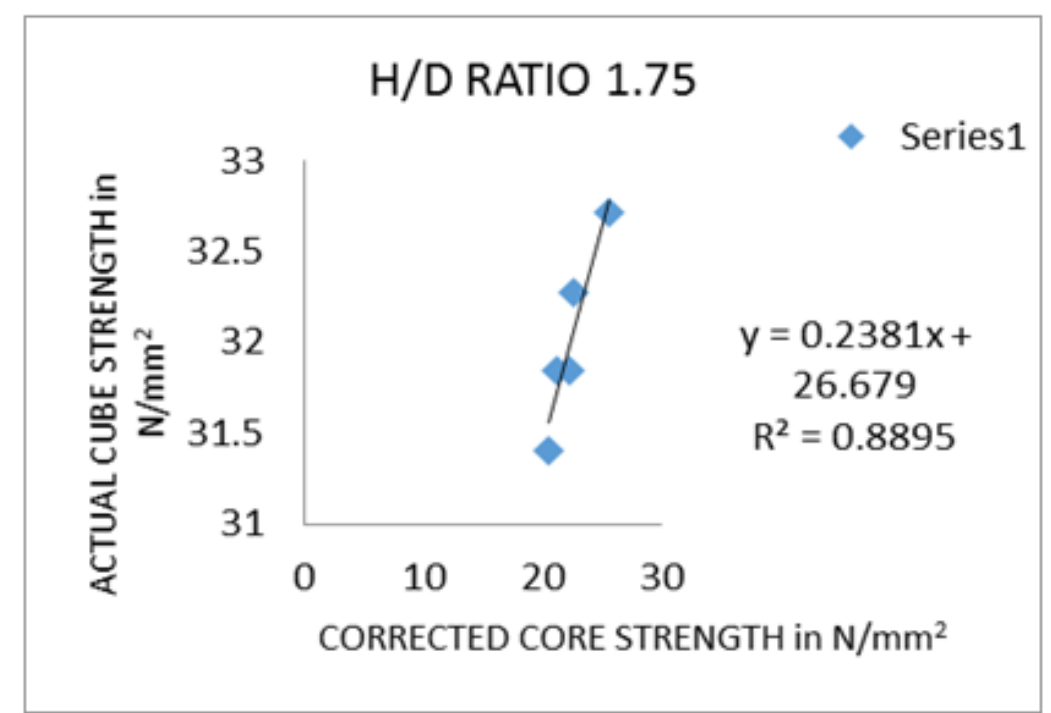

Fig.11 Correlation between actual cube strength and corrected core strength 


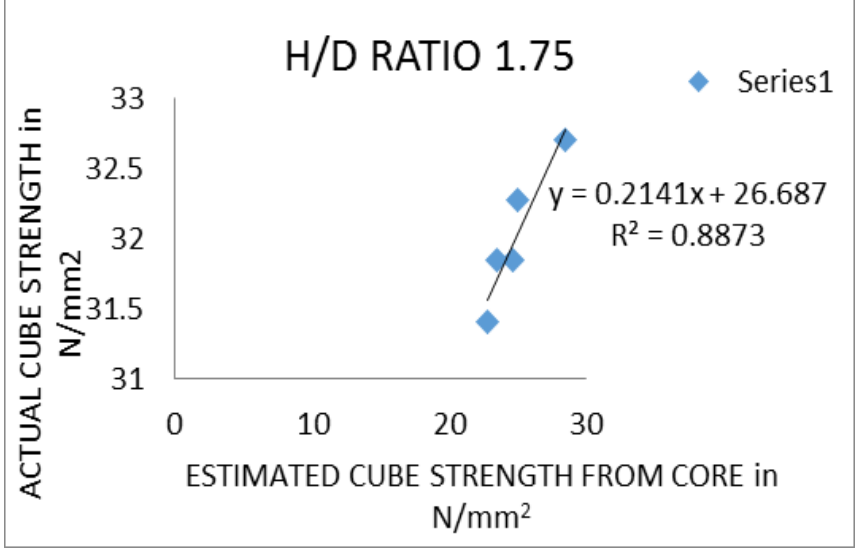

Fig.12 correlation between actual cube strength and estimated cube strength from core

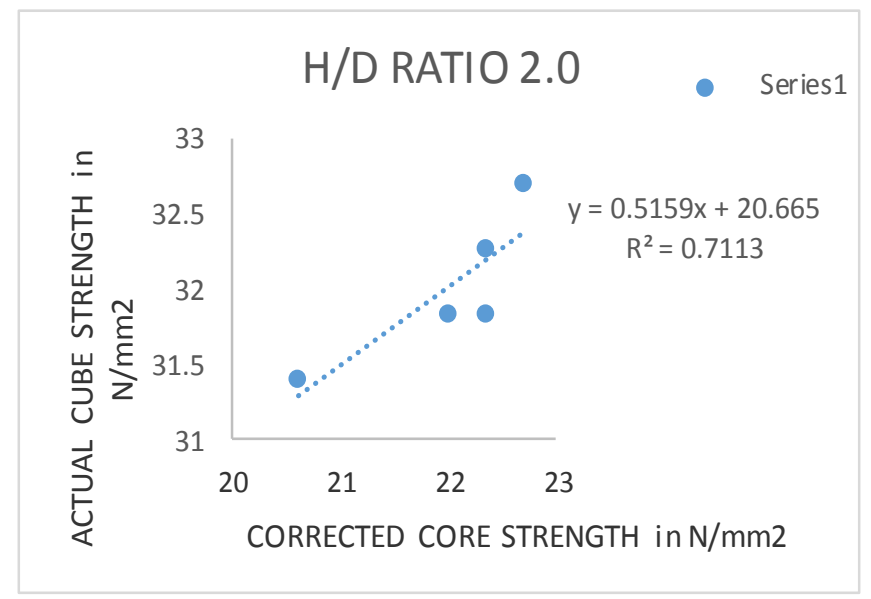

Fig.13 Correlation between actual cube strength and corrected core strength

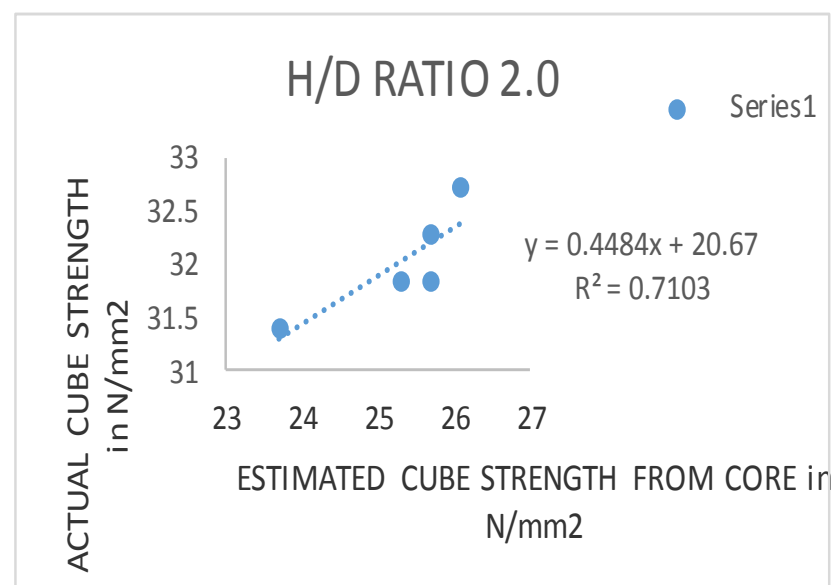

Fig.14 Correlation between actual cube strength and estimated cube strength from core

It is observed from fig.3, fig.4, fig.5, fig.6 fig.9, fig.10, fig.11, fig.12, the higher value of correlation coefficient is obtained for H/D ratio 1.5 and 1.75 and it is in the range between 0.863 to 0.920 . From fig.7, fig.8, fig.13, fig. 14 it is observed that a lower value of correlation coefficient is obtained. These correlation equations can be conveniently used to predict corrected core strength from rebound number and actual cube strength from corrected core strength, but however its application is limited to materials locally available. 
2) CORES WITH REINFORCEMENT

H/D RATIO 1.5

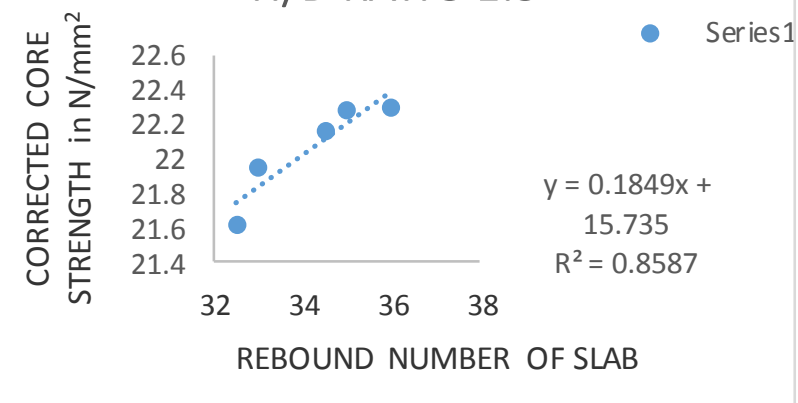

Fig. 15 correlation between corrected core strength and rebound number of slab

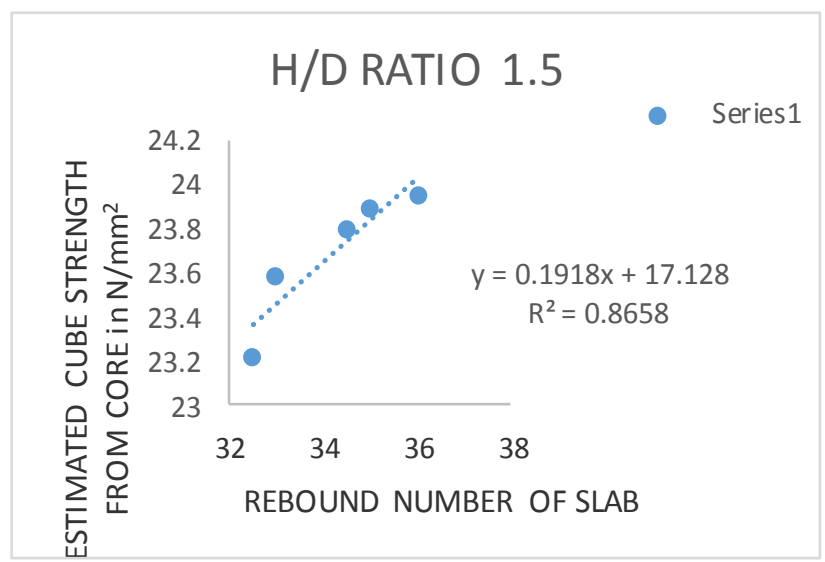

Fig. 16 correlation between estimated cube strength from core and rebound number of slab

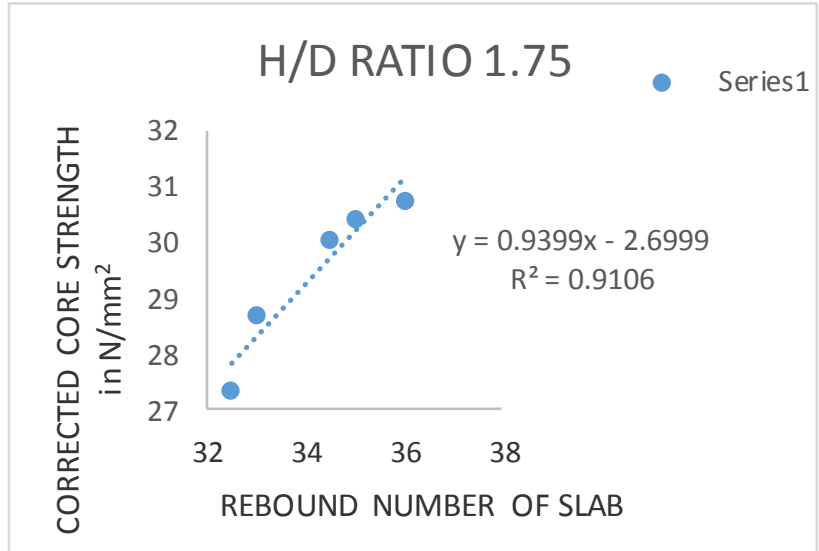

Fig. 17 correlation between corrected core strength and rebound number of slab

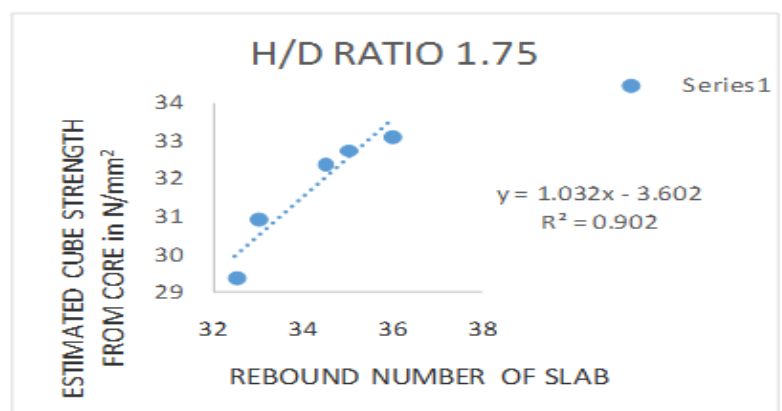

Fig. 18 correlation between estimated cube strength from core and rebound number of slab 


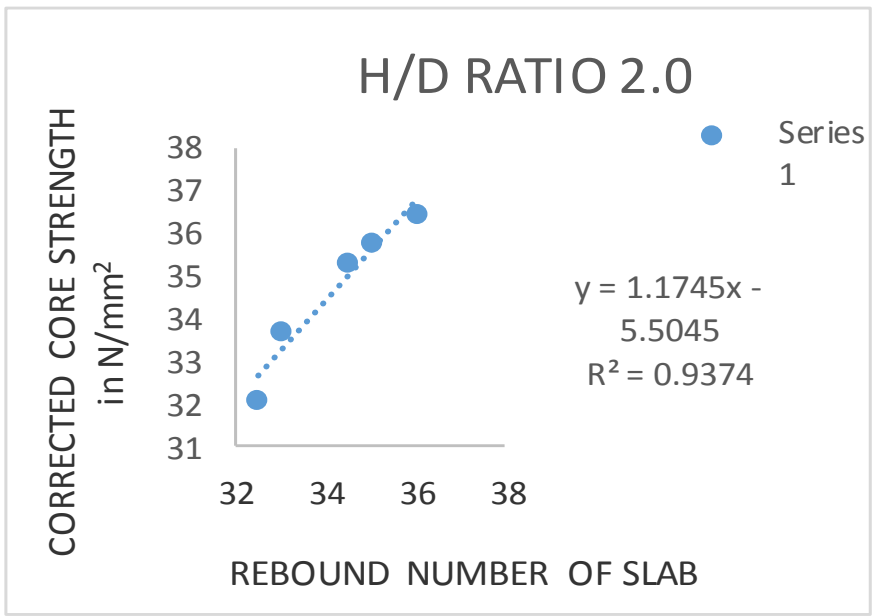

Fig. 19 correlation between corrected core strength and rebound number of slab

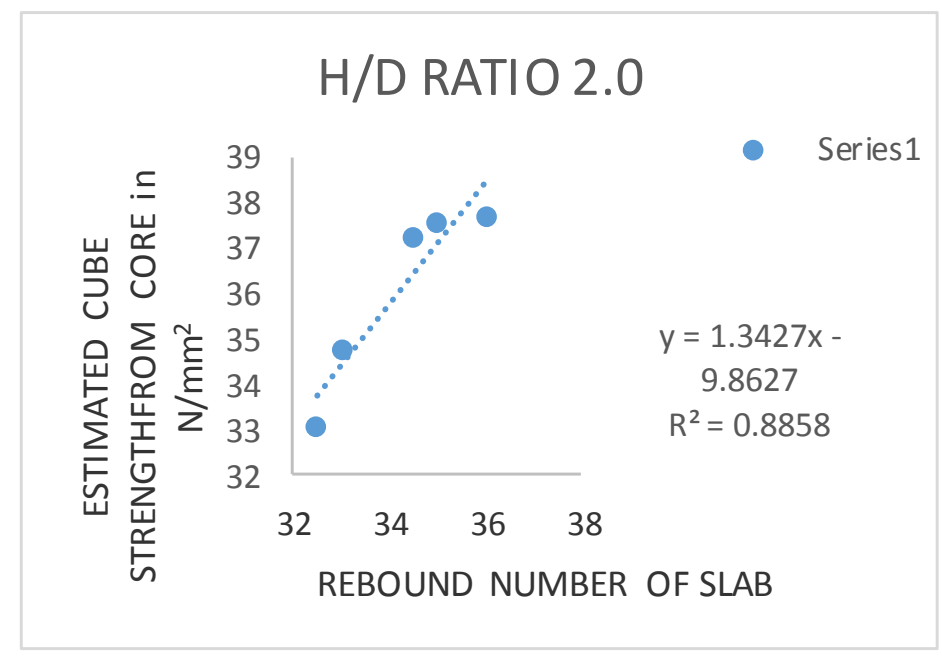

Fig. 20 correlation between estimated cube strength from core and rebound number of slab

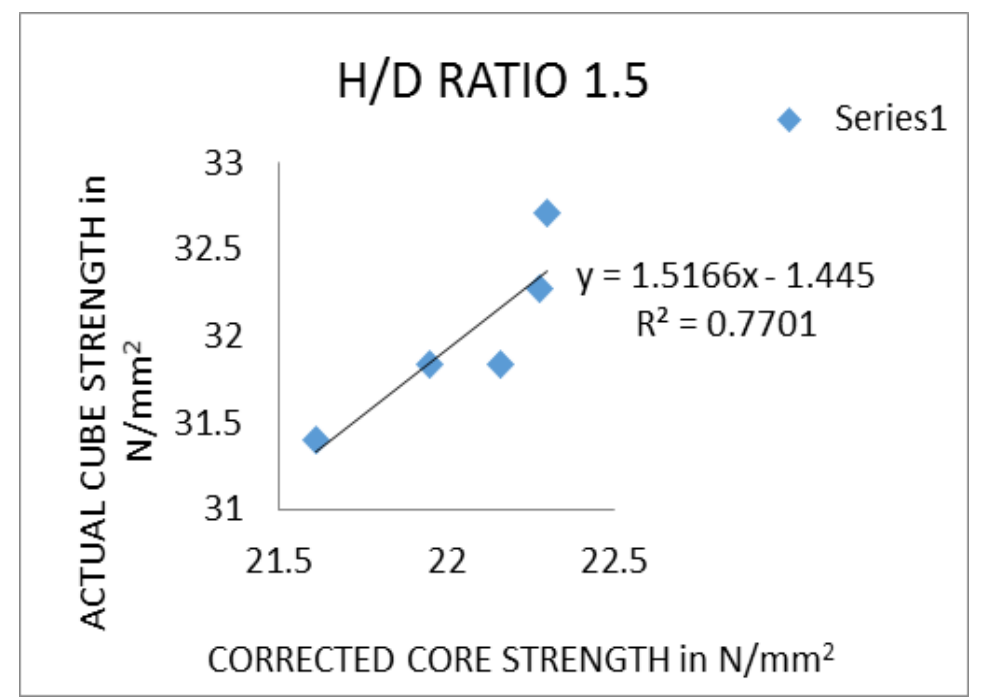

Fig.21 Correlation between actual cube strength and corrected core strength 


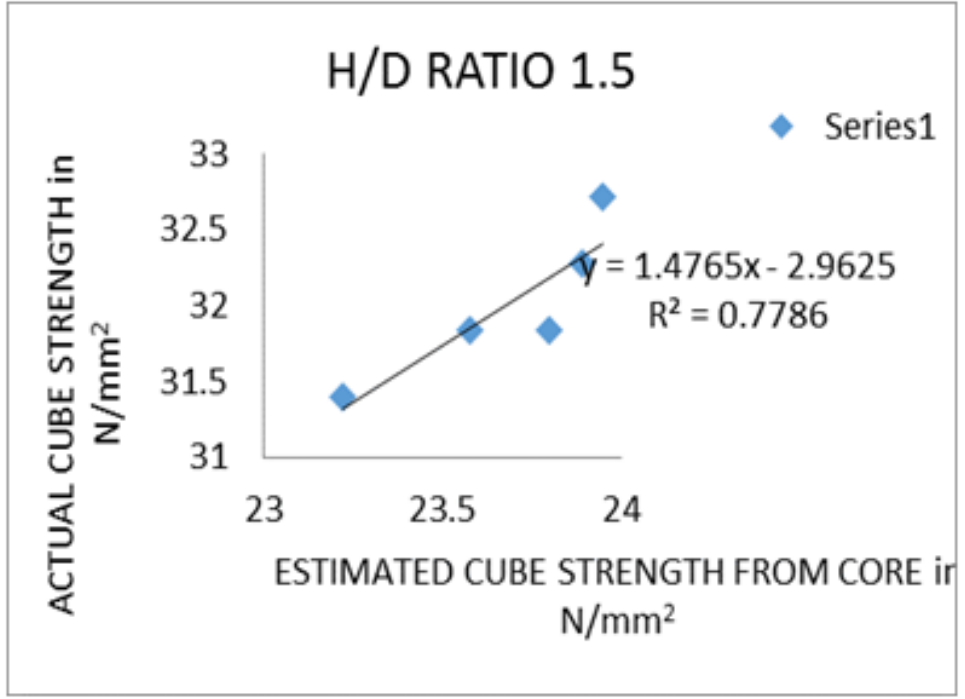

Fig.22 Correlation between actual cube strength and estimated cube strength from core

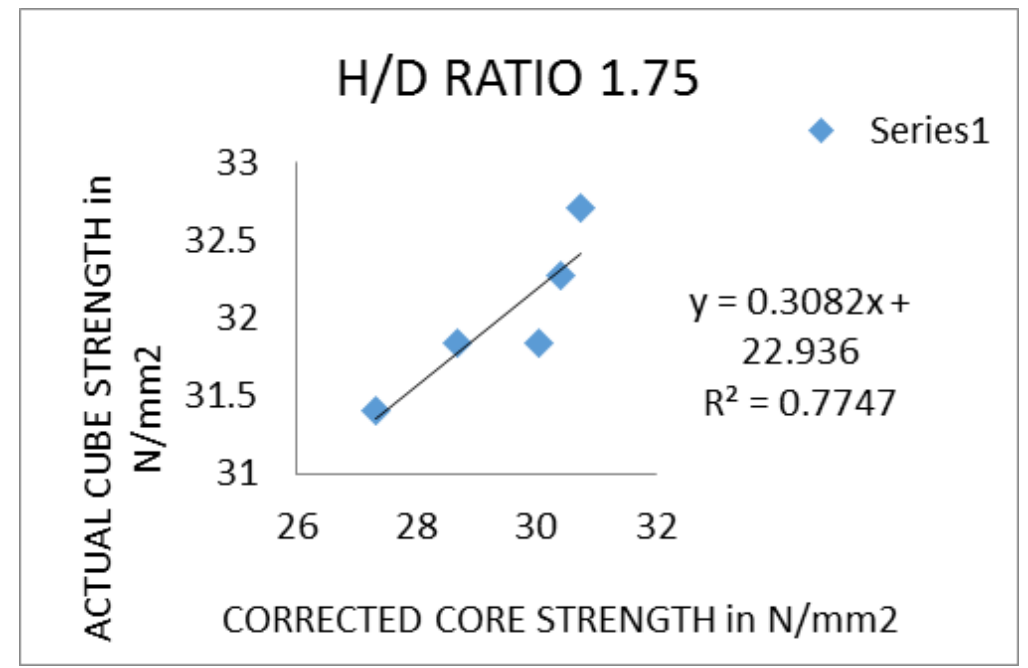

Fig.23 Correlation between actual cube strength and corrected core strength

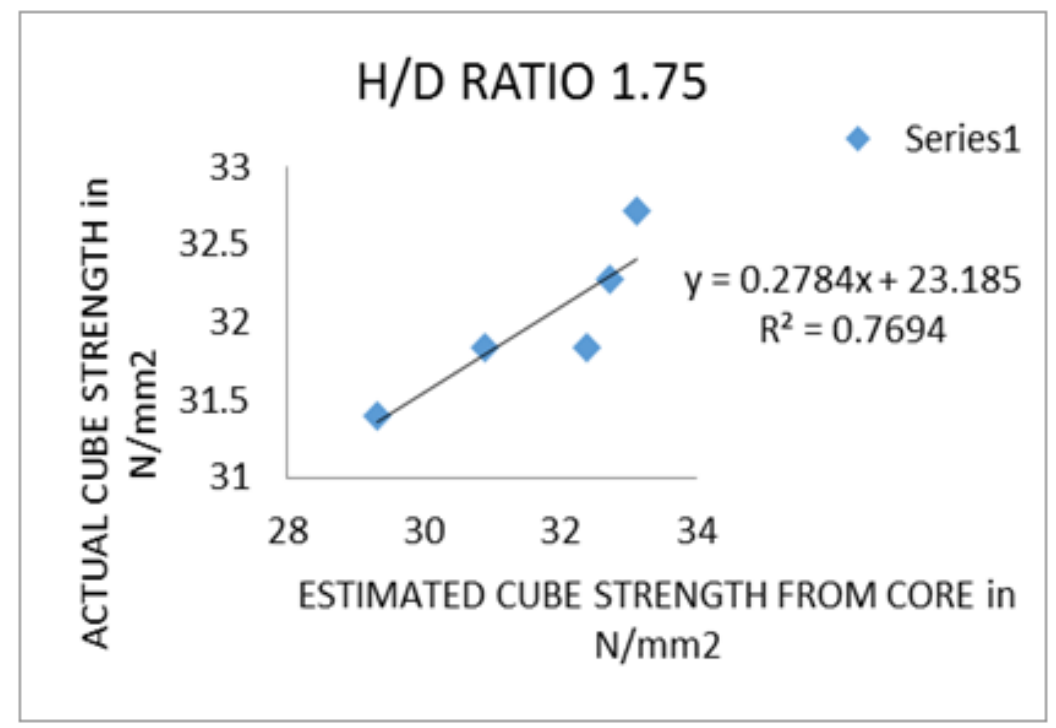

Fig.24 Correlation between actual cube strength and estimated cube strength from core 


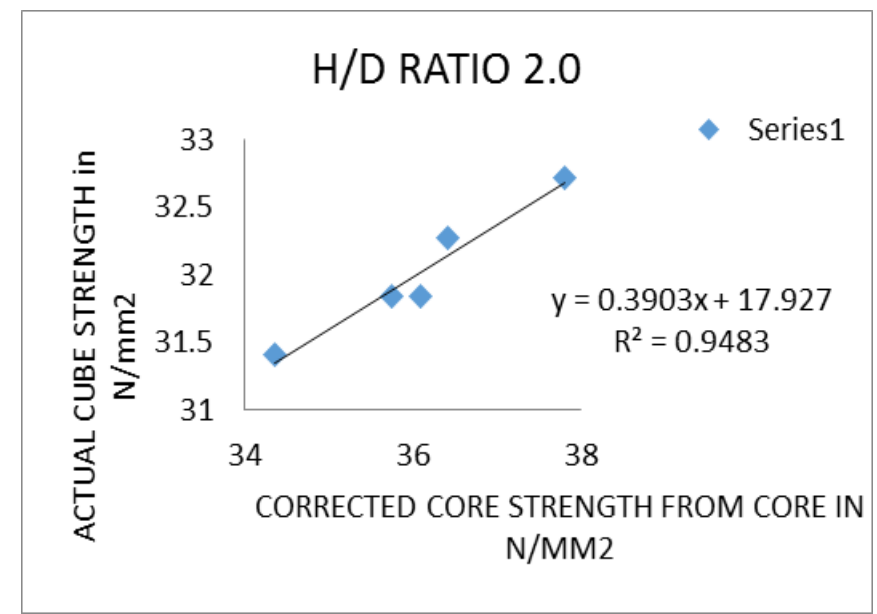

Fig.25 Correlation between actual cube strength and corrected core strength

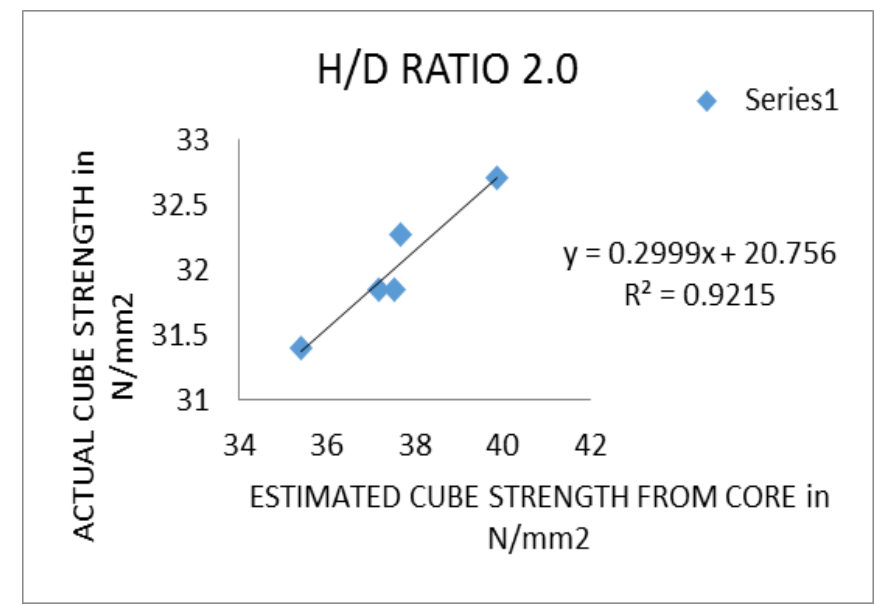

Fig.26 Correlation between actual cube strength and estimated cube strength from core

It is observed from fig.15, fig.16, fig.17 fig.18, fig.19 and fig.20 a good correlation coefficient is obtained in the range between 0.858 to 0.948 , similar behavior is observed for H/D ratio $1.5,1.75$ and 2.0 , but rebound number is irrespective of H/D ratio. These correlation equations can be conveniently used to predict corrected core strength from rebound number. It is observed From fig.21, fig.22, fig.23, fig.24 with H/D ratio $1.5,1.75$ a lower value of correlation coefficient is obtained, it is because of the restraining effect during the testing of cores due to lower H/D ratio For the with H/D ratio 2.0 restraining effect is minimum.

These correlation equations can be conveniently used to predict corrected core strength from rebound number and actual cube strength from corrected core strength, but however its application is limited to materials locally available.

\section{Conclusion}

1) The compressive strength obtained from the concrete cubes indicate greater strength as compared to measured core compressive strength for all the H/D ratio (1.5, 1.75 and 2.0). The core with reinforcement of $\mathrm{H} / \mathrm{D}$ ratio 2.0 has indicated greater core compressive strength as compared to cube compressive strength.

2) The cores free from reinforcement with H/D ratio $1.50,1.75$ and 2.0 indicate the lower core compressive strength as compared to cores with reinforcement for the same H/D ratios.

3) The core compressive strength increases with increase in the H/D ratio.

4) The corrected core compressive strength is 1.056 times the measured core compressive strength for all the three H/D ratio $(1.5,1.75$ and 2.0$)$.

a) Cores free from reinforcement

5) The correlation coefficient obtained between corrected core strength V/S rebound number of slab and estimated cube strength from core V/S rebound number of slab is nearly same for cores with H/D ratio 1.5 $(\mathrm{R}=0.955)$ and $1.75(\mathrm{R}=0.929)$ but for $H / \mathrm{D}$ ratio 2.0 lower value of correlation coefficient is obtained $(\mathrm{R}=0.850)$. 
6) The correlation coefficient obtained between actual cube strength V/S corrected core strength and actual cube strength V/S estimated cube strength from core is nearly same for cores with $\mathrm{H} / \mathrm{D}$ ratio $1.5(\mathrm{R}=0.939)$ and 1.75 $(\mathrm{R}=0.942)$, but for $\mathrm{H} / \mathrm{D}$ ratio 2.0 lower value of correlation coefficient is obtained $(\mathrm{R}=0.843)$.

\section{b) Cores with reinforcement}

7) The correlation coefficient obtained between corrected core strength V/S rebound number of slab and estimated cube strength from core V/S rebound number of slab is nearly same for cores with H/D ratio 1.5 $(\mathrm{R}=0.930)$ and $1.75(\mathrm{R}=0.953)$ and $2.0(\mathrm{R}=0.967)$

8) The correlation coefficient obtained between actual cube strength V/S corrected core strength and actual cube strength V/S estimated cube strength from core for H/D ratio 2.0 higher value of correlation coefficient is obtained $(\mathrm{R}=0.973)$, but lower value of correlation coefficient is obtained for $\mathrm{H} / \mathrm{D}$ ratio $1.5(\mathrm{R}=0.882)$ and 1.75 $(\mathrm{R}=0.879)$.

\section{References}

[1]. Sanita Rubene, M.sc.Eng., Martins Vilnitis, D.Sc., Ph.D., Eng., "Use Of The Schmidt Rebound Hammer For NDT Concrete Structure Testing In Field", Faculty Of Civil Engineering, Riga Technical University.

[2]. P.Turgut, Harren University, Engineering Faculty, Civil EngineeringDepartment Osmanbey Campus, Sanliurfa, Turkey.

[3]. Domagai Damja Nivie B.Sc., Josho Krolo, M.Sc., Ljudevit Hereeg, Ph.D., Faculty Of Civil Engineering University Of Zagreb, Crotia.

[4]. Raffacle Pucinotti, "Influence of Steel Reinforcement On Ultrasonic Pulse Velocity", Department Of Mechanicsand Materials, Mediterranean University Of Reggio Calabria, Italy.

[5]. M.A.Saleem, Z.A.Siddiqi, M.A.Javed and M.Aziz, "Non Destructive Evaluation Of An Existing Concrete Structure Using Load Test And Core Test", Department Of Civil Engineering, University Of Engineering And Technology, Lahore,Pak.J.Engg. And Applied Science Vol.11.July 2012.

[6]. A.Zacoeb and K.Ishibashi "Point Load Test Application for Estimating Compressive Strength of Concrete Structures from Small Core", ARPN Journal of Engineering And Applied Science Vol 4, No.7, September 2009.

[7]. M.Yaqub, M.Anjum Javed "Comparisonof Core and Cube Compressive Strength of Hardened Concrete", 31 ${ }^{\text {st }}$ Conference onOurWorld in Concrete andStructures: 16-17 August 2006, Singapore.

[8]. Ramesh Kumar G.B., "Non Destructive Testing In Distress Structures - An Overview", Journal of Basic and Applied Engineering Research, Volume Number 10; October 2014, pp. 114-119.

[9]. Dr.V. Karthikeyan, S.Loganathan, M.E., P.Venugopal, “AStudy On RC Columns And Slabs And Restoration Of RC Columns Of An ExistingMultistoriedBuilding”, InternationalJournal Of Engineering Innovation And Research Volume 2, Issue (2) ICEA - 2013.

[10]. Bohdan Stawiski, "Strength Of Concrete In Slabs, Investigates Along Direction Of Concreting", Open Journal Of Civil Engineering, 2012, 2, 22-26.

[11]. Kumavat H.R, Tapkire Ganesh, Patil P S, Chitte C.J, "Condition Assessment Of Concrete With NDT- Case Study", Volume: 03, Special Issue: 09, NCETCE - 2014.

[12]. Jedidi Malek, Machta Kaouther, "Destructive And Non Destructive Testing Of Concrete Structure", Jordan Journal Of Civil Engineering, Volume 8, No.4, 2014.

[13]. Kumavat H.R, Tapkire Ganesh, Patil P S, Chitte C.J, "Condition Assessment Of Concrete With NDT- Case Study", Volume: 03, Special Issue: 09, NCETCE - 2014

[14]. Dr. Isam H, Nashit, Saeed Hameed Abour, Anwar Abdullah Sadoon, "Ultrasonic Pulse Velocity in Concrete", NCCLR, Iraq - Bagdad.

[15]. IS 10262: 2009 "Concrete Mix Proportioning - Guidelines” BIS New Delhi; July 2009.

[16]. IS456: 2000 "Plain and Reinforced Concrete Code Of Practice” BIS New Delhi; July 2000.

[17]. ASCC "Technical Mcheck List Concrete Core Testing:June 2008. 